\title{
Risk factors for neurological dysfunctions after surgical repair of acute aortic dissection type $A$
}

\author{
Djordje Zdravkovic, Ivan Nesic, Igor Slavoljub Zivkovic, Marko Kaitovic, Petar Vukovic, Petar Milacic \\ Cardiac Surgery Department, Dedinje Cardiovascular Institute, Beograd, Serbia
}

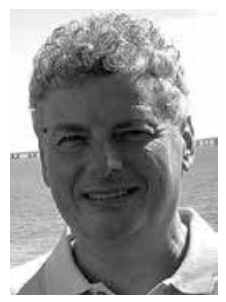

Kardiochir Torakochir Pol 2020; 17 (2): 70-75

\begin{abstract}
Introduction: Technical improvement and new operative strategies significantly influence survival and outcomes after the treatment of acute aortic dissection type A (AADA). However, postoperative complications and particularly neurological dysfunctions (ND) are still very common.

Aim: To identify preoperative and intraoperative factors as well as immediate postoperative conditions with an influence on the occurrence of neurological complications of surgical treatment of AADA and accordingly take action to reduce them.

Material and methods: Between January 2013 and December 2018, 240 patients with AADA were emergently surgically treated. All patients were divided into two groups: group I - patients with postoperative ND (subgroup la - patients with mild, transient ND and $\mathrm{lb}$ - patients with severe ND) and group II - patients without ND.

Results: Neurological damage after the operation was registered in 87 (39.5\%) patients. Thirty (13.6\%) patients had mild ND and 57 (25.9\%) severe. Presence of preoperative neurological deficit, reduced level of consciousness, supra-aortic vessel dissection, hemodynamic instability, and excessive postoperative bleeding with hypotension are factors with a highly statistically significant association with the occurrence of severe ND. Neurological complications were not identified in $66.7 \%$ of patients who were axillary cannulated versus $55.9 \%$ of patients cannulated in the other way but the difference did not reach statistical significance ( $p=0.1099)$.

Conclusions: Advanced neuroprotective strategies during surgical treatment of AADA are associated with favorable neurological outcomes, especially in a group of patients with identified risk factors for ND.
\end{abstract}

Key words: acute aortic dissection type A, neurological dysfunction, surgical treatment.

\section{Introduction}

The postoperative outcome of the surgical treatment of acute aortic dissection type A (AADA) has dramatically improved in the last two decades by advancing surgical strat-

\section{Streszczenie}

Wprowadzenie: Udoskonalenia techniczne i nowe strategie operacyjne znacząco poprawiają wyniki leczenia ostrego rozwarstwienia aorty typu A (AADA). Nadal jednak bardzo często obserwowane są powikłania pooperacyjne, zwłaszcza zaburzenia neurologiczne (ZN).

Cel pracy: Identyfikacja przed- i śródoperacyjnych czynników ryzyka oraz stanów występujących we wczesnym okresie pooperacyjnym, które mają wpływ na rozwój powikłań neurologicznych w leczeniu chirurgicznym AADA, a także odpowiednich działań umożliwiających ich ograniczenie.

Materiał i metody: Łącznie 240 chorych na AADA poddano leczeniu chirurgicznemu w trybie pilnym od stycznia 2013 r. do grudnia 2018 r. Pacjentów podzielono na dwie grupy: grupę I pacjenci z pooperacyjnymi ZN (podgrupa la - pacjenci z łagodnymi, przemijającymi ZN, podgrupa lb - pacjenci z ciężkimi ZN) i grupę II - pacjenci bez ZN.

Wyniki: Uszkodzenie neurologiczne po operacji stwierdzono u 87 (39,5\%) pacjentów. U 30 (13,6\%) obserwowano łagodne ZN, a u 57 (25,9\%) ciężkie ZN. Czynniki o wysokiej statystycznie istotnej zależności z występowaniem ZN o ciężkim przebiegu obejmują: przedoperacyjny deficyt neurologiczny, obniżony poziom świadomości, rozwarstwienie naczyń nadaortalnych, niestabilność hemodynamiczną i obfite krwawienie pooperacyjne z niedociśnieniem. Powikłań neurologicznych nie stwierdzono u 66,7\% pacjentów z kaniulą w tętnicy pachowej w porównaniu z 55,9\% pacjentów z kaniulą umieszczoną w innej tętnicy, jednak różnica nie była istotna statystycznie $(p=0,1099)$.

Wnioski: Zaawansowane strategie neuroprotekcyjne w leczeniu chirurgicznym AADA pozwalają uzyskać korzystny stan neurologiczny pacjentów, zwłaszcza w grupie z rozpoznanymi czynnikami ryzyka ZN.

Słowa kluczowe: ostre rozwarstwienie aorty typu A, zaburzenia neurologiczne, leczenie chirurgiczne.

egy. However, in addition to enforcement neuroprotective protocols such as hypodermic circulatory arrest (HCA), selective anterograde cerebral perfusion (SACP), and the cannulation approach, postoperative neurological disfunction

Address for correspondence: Igor Slavoljub Zivkovic MD, Cardiac Surgery Department, Dedinje Cardiovascular Institute, Beograd, Serbia, e-mail: igor88zivkovic@gmail.com

Received: 25.02.2020, accepted: 20.04.2020. 
(ND) still represents one of the most severe complications of this surgery, with an adverse and often fatal outcome [1-3]. In addition to initial neurological symptomatology developed as the consequence of the dissection itself, there is a high risk of occurrence of ND after surgical intervention $[1,4,5]$. It is believed that hypotension, inadequate cerebral perfusion due to the compromised true lumen of supraoptic vessels and thromboembolism are the main mechanisms of the development of cerebral ischemia and neurologic deficits [1]. Two basic types of neurological damage are described [6]:

1. Type I, which includes all major and moderate ND and coma as the extreme form of decreased awareness. Smaller focal cerebrovascular accidents that last more than 24 hours, as well as major epileptic attacks, are also forms of this type [5-7].

2. Type II includes a wide range of neurological manifestations, smaller volume, and lasting, such as temporary visual disturbances, minor epileptic attacks, deficits which last shorter than 24 hours, attention disorders, transient psychotogenic syndrome, and psychiatric disorders [5, 6, 8].

Listed type I ND are usually classified as transient, and type II as permanent neurological dysfunction, and they exist at discharge from hospital or at the moment of death.

\section{Aim}

The aim of this study is to identify preoperative and intraoperative factors as well as immediate postoperative conditions with an influence on the occurrence of neurological complications of surgical treatment of AADA and accordingly take action to reduce them.

\section{Material and methods}

Two hundred and forty consecutive patients operated on for AADA between January 2013 and December 2018 were divided into two groups: group I - patients with ND and group II - surgically treated patients without neurological symptomatology. Group I was additionally divided into two subgroups: group la - patients with mild, mostly reversible ND and group $\mathrm{Ib}$ - patients with severe, usually permanent ND and disorders of consciousness. All patients were operated on in emergency after computed tomography (CT) diagnostics. In the last 2 years, axillary cannulation with anterograde cerebral perfusion was established as a routine procedure considering the state of supra-aortic vessels (possible involvement of the subclavian artery by dissection). Postoperative neurological complications were diagnosed with neurological examination performed by a neurologist and verified most commonly with a CT examination of the head.

All data used in the study are available in medical records of the "Dedinje" Institute and in the existing internal database of patients with AADA.

\section{Statistical analysis}

For statistical analysis we used the EZR program (version 1.33). Categorical variables were compared using the
Table I. Types of postoperative neurological disfunction (ND)

\begin{tabular}{lc} 
Type of ND & Number of patients \\
\hline Disorientation & $32(14.5 \%)$ \\
\hline Agitation & $31(14.1 \%)$ \\
\hline Psychoorganic syndrome & $16(7.3 \%)$ \\
\hline Paresis and paralysis & $49(22.3 \%$ \\
\hline Speech disorders & $6(2.7 \%)$ \\
\hline Sopor and coma & $29(13.2 \%)$ \\
\hline
\end{tabular}

ND - neurological dysfunction.

$\chi^{2}$ and Fisher test. Significance was defined as statistically significant for $p$-values $<0.05$ and highly statistically significant for $p$-values $<0.01$.

\section{Results}

Between January 2013 and December 2018 two hundred forty patients with AADA were operated on. Twenty (8.3\%) patients died in the operating room or in the first 24 hours after the operation due to massive hemorrhage and/or heart failure, and they were not included in the study analysis. The rate of preoperatively neurological deficit in group la, group Ib, and group II was (23.3\%, 42.1\%, and $13.5 \%$ respectively). Four patients with mild neurological symptoms during admission to hospital postoperatively recovered neurological function. Patients with severe neurological deficits preoperatively had the same or worse neurological function after operations. Postoperative ND was registered in the 5 patients who did not have neurological symptomatology preoperatively.

Neurological symptomatology after surgical treatment was found in 87 (39.5\%) patients. Isolated mild reversible ND such as disorientation, agitation, temporary limb weakness, and psychoorganic syndrome were found in 30 (13.6\%) patients. Severe neurological complications (plegia and irreversible limb weakness, speech disorders, and severe consciousness disturbance and coma) were found in $57(25.9 \%)$ patients, and a few of these patients had at the same time some mild ND (Table I).

\section{Preoperative factors and postoperative neurological dysfunctions}

Males operated on for AADA had postoperative neurological complications more often than females $(81.6 \%$ of patients with postoperative ND were males, and $42 \%$ of managed males developed ND versus $30.8 \%$ of operated females). Nevertheless, the difference did not have statistical significance $(p=0.1386)$. The average age of patients in group I is 58.9 years, and in group II 57.6 years, and there is no significant difference between groups.

Reduced level of consciousness, CT registered supraaortic vessel dissection, neurological deficit, cardiopulmonary reanimation, and intubation of the patient on admission to the hospital or immediate preoperative period are factors with high statistical significance, and they can be considered as predisposing for the occurrence of postop- 
Table II. Preoperative factors and postoperative neurological complications $(n=220)$

\begin{tabular}{|c|c|c|c|c|c|}
\hline Parameter & $\begin{array}{l}\text { Group I } \\
(n=87)\end{array}$ & $\begin{array}{l}\text { Group la } \\
(n=30)\end{array}$ & $\begin{array}{l}\text { Group Ib } \\
(n=57)\end{array}$ & $\begin{array}{l}\text { Group II } \\
(n=133)\end{array}$ & $P$-value \\
\hline Prior CVI, TIA and consciousness disturbance & $20(23 \%)$ & $6(20 \%)$ & $14(24.6 \%)$ & $23(17.3 \%)$ & $\begin{aligned} & \mathrm{I} \rightarrow \mathrm{II}, 0.3 \\
& \mathrm{la} \rightarrow \mathrm{II}, 0.7 \\
& \mathrm{Ib} \rightarrow \mathrm{II}, 0.2\end{aligned}$ \\
\hline \multicolumn{6}{|l|}{ Time from the first symptoms } \\
\hline$<12$ hours & $24(27.6 \%)$ & & & $36(27.1 \%)$ & $\mathrm{I} \rightarrow \mathrm{II}, 0.9$ \\
\hline$>12$ hours & $63(72.4 \%)$ & & & $97(72.9 \%)$ & \\
\hline Supra-aortic vessels dissection & $47(54 \%)$ & $12(40 \%)$ & $35(61 \%)$ & $40(30.1 \%)$ & $\begin{array}{c}\mathrm{I} \rightarrow \mathrm{II},<0.01 \\
\mathrm{Ia} \rightarrow \mathrm{II}, 0.3 \\
\mathrm{Ib} \rightarrow \mathrm{II},<0.01\end{array}$ \\
\hline Intubation on admission & $14(16.1 \%)$ & $1(3.3 \%)$ & $13(22.8 \%)$ & $5(3.8 \%)$ & $\begin{array}{c}\mathrm{I} \rightarrow \mathrm{II},<0.01 \\
\mid \mathrm{a} \rightarrow \mathrm{II}, 0.9 \\
\mid \mathrm{b} \rightarrow \mathrm{II},<0.01\end{array}$ \\
\hline Hypotension and CPR & $27(31 \%)$ & $3(10 \%)$ & $24(42.1 \%)$ & 19 (14.3\%) & $\begin{array}{c}\mathrm{I} \rightarrow \mathrm{II},<0.01 \\
\mathrm{la} \rightarrow \mathrm{II}, 0.5 \\
\mathrm{Ib} \rightarrow \mathrm{II},<0.01\end{array}$ \\
\hline Consciousness disturbance on admission & 17 (19.5\%) & $1(3.3 \%)$ & $16(28.1 \%)$ & $5(3.8 \%)$ & $\begin{array}{c}\mathrm{I} \rightarrow \mathrm{II},<0.01 \\
\mathrm{la} \rightarrow \mathrm{II}, 1.0 \\
\mathrm{Ib} \rightarrow \mathrm{II},<0.01\end{array}$ \\
\hline Neurological deficits on admission & $33(37.9 \%)$ & $7(23.3 \%)$ & $26(42.1 \%)$ & $18(13.5 \%)$ & $\begin{array}{c}\mathrm{I} \rightarrow \mathrm{II},<0.01 \\
\mid \mathrm{la} \rightarrow \mathrm{II}, 0.18 \\
\mathrm{Ib} \rightarrow \mathrm{I},<0.01\end{array}$ \\
\hline
\end{tabular}

CVI - cerebrovascular ischemia, TIA - transient ischemic attack, CPR - cardiopulmonary resuscitation.

Table III. Neurological outcome depending on involvement of aortic arch in reconstruction

\begin{tabular}{lccc} 
Group & $\begin{array}{c}\text { Total arch } \\
\text { replacement } \\
(n=17)\end{array}$ & $\begin{array}{c}\text { Other types } \\
\text { of reconstruction } \\
(n=203)\end{array}$ & P-value \\
$\begin{array}{l}\text { Group I } \\
\text { ND }+\end{array}$ & $9(52.9 \%)$ & $78(38.4 \%)$ & 0.033 \\
\hline $\begin{array}{l}\text { Group Ia } \\
\text { Mild ND }\end{array}$ & $1(5.9 \%)$ & $29(14.3 \%)$ & 0.273 \\
\hline $\begin{array}{l}\text { Group Ib } \\
\text { Severe ND }\end{array}$ & $8(47.1 \%)$ & $49(24.1 \%)$ & 0.002 \\
\hline $\begin{array}{l}\text { Group II } \\
\text { ND - }\end{array}$ & $8(47.1 \%)$ & $125(61.6 \%)$ & 0.03 \\
\hline
\end{tabular}

ND - neurological dysfunction.

Table IV. Axillary versus other cannulation sites - neurological outcome

\begin{tabular}{lccc} 
Group & $\begin{array}{c}\text { Axillary } \\
\text { cannulation } \\
(n=93)\end{array}$ & $\begin{array}{c}\text { Other } \\
\text { cannulation sites } \\
(n=127)\end{array}$ & P-value \\
$\begin{array}{l}\text { Group I } \\
\text { ND + }\end{array}$ & $31(33.3 \%)$ & $56(44.1 \%)$ & 0.1 \\
\hline $\begin{array}{l}\text { Group Ia } \\
\text { Mild ND }\end{array}$ & $11(11.8 \%)$ & $19(14.7 \%)$ & 0.2 \\
\hline $\begin{array}{l}\text { Group Ib } \\
\text { Severe ND }\end{array}$ & $20(21.5 \%)$ & $37(29.1 \%)$ & 0.2 \\
\hline $\begin{array}{l}\text { Group II } \\
\text { ND - }\end{array}$ & $62(66.7 \%)$ & $71(55.9 \%)$ & 0.1 \\
\hline
\end{tabular}

ND - neurological dysfunction. erative ND, particularly severe. None of the mentioned factors influenced the development of mild ND. Prior cerebrovascular ischemia (CVI), transient ischemic attack (TIA), as well as the elapsed time from the first symptoms of dissection had no impact on the occurrence of postoperative ND (Table II).

\section{Intraoperative factors and postoperative neurological complications}

$52.4 \%$ of patients with total arch replacement and reconstruction of supra-aortic vessels (9 of 17) had neurological complications and $47.1 \%$ (8 patients) severe postoperative ND. In a group of patients in whom arcus of the aorta and supra-aortic vessels were not surgically treated, $78(38.4 \%)$ patients had neurological complications, and $49(24.2 \%)$ severe ND. Obviously, in total, arch group neurological complications are more common $(p=0.03)$, particularly severe neurological damage $(p=0.002)$ (Table III). Almost $65 \%$ of patients with axillary cannulation did not show neurological complications versus $56 \%$ in the group with another cannulation strategy (aorta, femoral artery, apical cannulation), although the difference is not statistically significant ( $p=0.1099$ for the entire group of $p a-$ tients with postoperative ND, $p=0.2592$ for group la and $p=0.1415$ for group $\mathrm{lb}$ ). Concerning neurological outcome, especially the occurrence of severe ND, axillary cannulation showed superiority versus femoral cannulation, while in comparison with apical cannulation, markedly better results were not registered (Tables IV-VI). Use of ACP, even in patients with circulatory arrest longer than 60 minutes, was not followed in our series by a significantly lower in- 
Table V. Axillary versus femoral cannulation - neurological outcome

\begin{tabular}{lccc} 
Group & $\begin{array}{c}\text { Axillary } \\
\text { cannulation }(n=93)\end{array}$ & $\begin{array}{c}\text { Femoral } \\
\text { cannulation }(n=37)\end{array}$ & P-value \\
$\begin{array}{l}\text { Group I } \\
\text { ND + }\end{array}$ & $31(33.3 \%)$ & $16(43.2 \%)$ & 0.1 \\
\hline $\begin{array}{l}\text { Group Ia } \\
\text { Mild ND }\end{array}$ & $11(11.8 \%)$ & $3(8.1 \%)$ & 0.6 \\
\hline $\begin{array}{l}\text { Group Ib } \\
\text { Severe ND }\end{array}$ & $20(21.5 \%)$ & $13(35.1 \%)$ & 0.05 \\
\hline $\begin{array}{l}\text { Group II } \\
\text { ND - }\end{array}$ & $62(66.7 \%)$ & $21(56.8 \%)$ & 0.3 \\
\hline
\end{tabular}

ND - neurological dysfunction.
Table VI. Axillary versus left ventricular apex cannulation - neurological outcome

\begin{tabular}{lccc} 
Group & $\begin{array}{c}\text { Axillary } \\
\text { cannulation }(n=93)\end{array}$ & $\begin{array}{c}\text { Left ventricular apex } \\
\text { cannulation }(n=79)\end{array}$ & P-value \\
$\begin{array}{l}\text { Group I } \\
\text { ND + }\end{array}$ & $31(33.3 \%)$ & $35(44.3 \%)$ & 0.1 \\
\hline $\begin{array}{l}\text { Group Ia } \\
\text { Mild ND }\end{array}$ & $11(11.8 \%)$ & $14(17.7 \%)$ & 0.2 \\
\hline $\begin{array}{l}\text { Group Ib } \\
\text { Severe ND }\end{array}$ & $20(21.5 \%)$ & $21(26.6 \%)$ & 0.3 \\
\hline $\begin{array}{l}\text { Group II } \\
\text { ND - }\end{array}$ & $62(66.7 \%)$ & $44(55.7 \%)$ & 0.4 \\
\hline
\end{tabular}

ND - neurological dysfunction.

Table VII. Postoperative hypotension and excessive bleeding and neurological complications

\begin{tabular}{|c|c|c|c|c|c|}
\hline Parameter & $\begin{array}{l}\text { Group I } \\
(n=87)\end{array}$ & $\begin{array}{l}\text { Group la } \\
(n=30)\end{array}$ & $\begin{array}{l}\text { Group Ib } \\
(n=57)\end{array}$ & $\begin{array}{l}\text { Group II } \\
(n=133)\end{array}$ & $P$-value \\
\hline Postoperative hypotension & 27 (31\%) & $4(13.3 \%)$ & $23(40.4 \%)$ & $20(15 \%)$ & $\begin{array}{c}\mathrm{I} \rightarrow \mathrm{II},<0.01 \\
\mathrm{Ia} \rightarrow \mathrm{II}, 0.8 \\
\mathrm{Ib} \rightarrow \mathrm{I},<0.01\end{array}$ \\
\hline Rethoracotomy for hemostasis & $25(28.7 \%)$ & $3(10 \%)$ & $22(38.6 \%)$ & $21(15.8 \%)$ & $\begin{array}{c}\mathrm{I} \rightarrow \mathrm{II},<0.05 \\
\mathrm{Ia} \rightarrow \mathrm{II}, 0.4 \\
\mathrm{Ib} \rightarrow \mathrm{I},<0.01\end{array}$ \\
\hline
\end{tabular}

cidence of neurological complications (62.4\% vs. $58.6 \%$, $p=0.8811)$. Hypothermic circulatory arrest duration in group I, IA, and Ib (48.1 minutes, 44.4 minutes, and 49.9 minutes) are longer compared with group II (37.5 minutes), but the difference is not statistically significant. A similar relation is between extracorporeal circulation duration (161.8 minutes, 160.4 minutes, and 164.5 minutes vs. 153.5 minutes).

\section{Immediate postoperative conditions and neurological complications}

Hypotension and CPR in the immediate postoperative course and rethoracotomy for hemostasis in the first 72 hours after the operation are highly significantly associated with the occurrence of severe ND (Table VII).

\section{Hospital stay and mortality}

The neurological estimation was checked during postoperative awakening. If uncorrected awakening or neurological deficit existed, neurologists performed examination of patients. The persisting ND was evaluated by CT scan in the patients with satisfactory hemodynamic parameters. Patients with neurological complications stayed longer in the hospital than patients without neurological disturbance ( 25 days vs. 15 days). Transient ND was recovered before the hospital discharge. The severity of ND did not have a significant influence on the duration of hospitalization, although it was longer in the group with severe ND (29 days vs. 24 days).

The total mortality of all 240 operated patients was $26.7 \%$ (64 patients). The death rate of patients with postoperative ND was $39.1 \%$ (34 patients), and it is highly statistically significantly higher compared with the group of patients without ND $(7.5 \%, p<0.01)$. The most common
Table VIII. Mortality of operated patients

\begin{tabular}{lcccc}
$\begin{array}{l}\text { Group I } \\
(n=87)\end{array}$ & $\begin{array}{c}\text { Group la } \\
(n=30)\end{array}$ & $\begin{array}{c}\text { Group Ib } \\
(n=57)\end{array}$ & $\begin{array}{c}\text { Group II } \\
(n=133)\end{array}$ & P-value \\
\hline $34(39.1 \%)$ & $5(16.7 \%)$ & $29(50.9 \%)$ & $10(7.5 \%)$ & $\begin{array}{l}\text { I } \rightarrow \text { II, }<0.01 \\
\text { Ia } \rightarrow \text { II, } 0.1 \\
\text { Ib } \rightarrow \| \text { II, }<0.01\end{array}$ \\
\hline
\end{tabular}

reason for early mortality within 24 hours after the operation was fatal bleeding or heart failure due to malperfusion syndrome of the coronary artery. The neurological deficit increased the late in-hospital mortality rate. The difference is more pronounced when compared to group $\mathrm{lb}$ and group II $(50.9 \%$ vs. $7.5 \%, p<0.01)$. The mortality of patients with mild ND (16.7\%) is double that in group II, but the difference is not statistically significant $(p=0.1174)$ (Table VIII). The most common causes of death in group la and group II were postoperative bleeding, heart failure or respiratory failure; these patients died in the early postoperative period, 1 (IQR 1-3) day. Severe neurological deficit was associated with late death outcomes, 10 (IQR 10-16) days.

The mortality rate was insignificantly higher in the patients in whom apical cannulation was performed ( $p=0.1$ ). Probably these patients needed emergent cannulation and cardio-pulmonary bypass.

\section{Discussion}

From 220 analyzed patients, ND were observed in 87 (39.5\%), which is a number higher than we found in the literature (Sinatra et al. $24.7 \%$ of 85 patients, Conzelmann et al. $17.2 \%$ of 237 patients, Kim et al. $31.4 \%$ of 188 patients) $[5,9,10]$. Even though there are studies with a higher frequency of ND (Gaul et al. 47.5\% of 102 patients) [4]. Se- 
vere ND occurred in 57 patients (25.9\%) that is also a little higher than in other studies (Dumfarth et al. 15.8\% of 303 patients with postoperative stroke, Bassano et al. $12.3 \%$ of 102 patients, Wiederman et al. 16\% of 329 patients) [1, 2, 11], but it must be considered that in those studies it was only about permanent ND and that some of them did not include patients with preoperative ND [2].

Supra-aortic vessels dissection and cerebral malperfusion can lead to more frequent occurrence of postoperative ND for the following reasons: 1 . Operation in full heparinization in the condition of cerebral ischemia could provoke conversion of ischemic to hemorrhagic cerebral infarction; 2. additional cerebral malperfusion during extracorporeal circulation; 3. cerebral reperfusion leading to worsening of existing ND $[12,13]$. Conzelmamm et al. indicate supra-aortic vessel dissection as a preoperative risk factor for postoperative ND. The same conclusion about the association with new ND after the operation was reached by Cherny et al in a study on 523 patients [14]. However, Dumfarth et al. state that dissection of the supra-aortic vessels is not a risk factor for postoperative stroke (dissected innominate artery in patients with stroke $62.5 \%$ vs. $56.5 \%$ in patients without stroke, $p=0.529$ and right carotid artery dissection $39.5 \%$ in patients with stroke vs. $27.5 \%$ in patients without stroke, $p=0.119$ ) [1].

Preoperative neurological symptomatology, consciousness disturbances, hemodynamic instability, hypotension, and CPR and intubation of the patient on admission to hospital are undoubtedly factors highly statistically related to postoperative ND attendance. In Dumfarth's study, patients with postoperative stroke were in significantly worse hemodynamic condition on admission (18.8\% vs. $3.5 \%$, $p<0.01$ ) [1]. The same study also points to the significant correlation between preoperative and postoperative ND ( $25 \%$ vs. $11.8 \%, p=0.022$ ), as well as cerebral malperfusion syndrome before the operation ( $47.9 \%$ vs. $22.4 \%, p<0.01)$. Although the mentioned factors in our study only affect the onset of severe ND, Haldenwang et al. identified poor preoperative mental condition as a preoperative risk factor for temporary postoperative ND [3].

Short time from the onset of first symptoms to surgery did not show any conclusive association with a lower frequency of neurological complications and improvement of eventual primary neurological deficits. Most studies, however, show that the best results are achieved with the operation started within 10 hours. Morimoto et al. reported that elapsed time more than 9.1 hours is related to the failure of neurological recovery [15]. Tsukube et al. and Orihashi even opine that the optimal time for the neurological operation is 5 hours $[12,16]$ with an additional neuroprotective strategy: initial deep hypothermia and ACP following by mild hypothermia in intensive care and postoperative magnesium treatment. The fact that practically none of our patients had been operated on within the golden 10-hour period is the reason for the absence of similar results in our study.

The number of patients with total arch replacement was not too big (17 of 220 patients), but obviously, neurological complications, particularly severe neurological damage, follow more often total arch replacement than another type of reconstruction of the aorta where supra-aortic vessels were not covered with the repair. Data presented by Kim et al. with a much higher incidence of newly developed ND after total arch replacement $(47.7 \%$ vs. $26.4 \%, p=0.003)$ [10] are quite similar, unlike data of the GERAADA group, who compared the onset of postoperative neurological deficits between the total arch and Hemi arcus group, without a significant difference between groups (13.6\% vs. $12.5 \%$, $p=781)$ [17].

Cerebral protection, which includes cannulation of the right axillary artery, ACP, and measurement of cerebral oximetry during operation, was applied in most of the analogous studies [18].

Our study, however, did not show a statistically significant difference related to the other cannulation choice, but axillary cannulation and ACB showed an important tendency toward better results, considering postoperative neurological condition, particularly related to the femoral artery cannulation. The reason for lack of statistical significance lies in the fact that axillary cannulation was established in our institution as a routine procedure just in the 2-3 last years. The most commonly used cannulation strategy in the previous period of time was left ventricle apex cannulation, and it showed very good results, specifically in hemodynamically unstable patients, enabling the rapid establishment of extracorporeal circulation and cooling the patient for circulatory arrest. A similar reason exists for the absence of positive effects of ACP, with an additional onethe relatively small number of patients with circulatory arrest longer than 60 minutes (37 patients $-16.8 \%$ ). Despite a few other studies where there was no significant difference in the incidence of cerebral complications between axillary and femoral cannulation (Lee et al.), many more studies have shown the superiority of axillary cannulation [19-21].

Postoperative ND, mild and severe, are extending hospitalization stay and thus seriously increase the cost of treatment. However, a more serious consequence of neurological complications is significantly higher hospital mortality, primarily in patients with severe ND (50.9\%). The most common cause of death is heart failure or multiorgan failure, and those patients mostly have severe consciousness disturbance and coma. Mortality in patients with mild ND is almost double that in patients without ND, which cannot be ignored, although statistical significance does not exist.

Absence of reliable assessment of preoperative neurological condition performed by a neurologist and precise determination of the degree of neurological damage and depth of consciousness disorder.

Unreliable data about time since the first symptoms of aortic dissection to the hospital admission for operative treatment.

CT scan examination was often done in the regional medical center without direct insight into CT findings (only the description given by a regional doctor was available). 


\section{Conclusions}

Based on the study data, all identified risk factors are exclusively related to the development of severe ND. The fact that we did not find any single risk factor for the appearance of mild ND indicates the need to use a different study design which could detect them, considering their great medical importance (prolonged hospitalization and higher mortality).

On the other hand, powerful risk factors for the development of severe postoperative neurological damage were detected. It is essential to define in advance an operative strategy in relation to the type of reconstruction, choice of the cannulation site, and cerebral protection in order to establish normal cerebral perfusion as soon as possible, especially in patients identified as being at high risk for postoperative neurological damage.

\section{Disclosure}

Authors report no conflict of interest.

\section{References}

1. Dumfarth J, Kofler M, Stastmy L, et al. Stroke after emergent surgery for acute type $\mathrm{A}$ aortic dissection: predictors, outcome and neurological recovery. Eur J Cardiothorac Surg 2018; 53: 1013-1020.

2. Bassano C, Nardi P, Colella DF, et al. Neurologic dysfunction after aortic dissection surgery: different cerebral hypothermic antegrade perfusion techniques. J Anesth Clin Res 2018; 9: 4.

3. Haldenwang PL, Wahlers T, Himmels A, et al. Evaluation of riski factors for transient neurological dysfunction and adverse outcome after repair of acute type A aortic dissection in 122 consecutive patients. Eur J Cardiothorac Surg 2012; 42: 115-120.

4. Gaul C, Dietrich W, Friedrich I, et al. Neurologic symptoms in type A aortic dissection. Stroke 2007; 38: 292-297.

5. Conzelmann LO, Hoffmann I, Blettner M, et al.; the GERAADA investigators. Analysis of risk factors for neurological dysfunction in patients with acute aortic dissection type A: data from German Registry for Acute Aortic Dissection Type A (GERAADA). Eur J Cardiothorac Surg 2012; 42: 557-565.

6. Koullias GJ, Elefteriades JA. Neurological complications in cardiac surgery. In: Complications in Cardio-thotacic Surgery: Avoidance and Treatment. $1^{\text {st }}$ ed. Alex LG (eds). Blackwell Publishing Inc.Futura Division; New York 2004; 405-435.
7. Kumral E, źuksel M, Büket S, et al. Neurologic complications after deep hypothermic circulatory arrest: types, predictors and timing. Tex Heart Inst 2001; 28: 83-88.

8. Lee $\mathrm{SJ}, \mathrm{Kim} \mathrm{JH}, \mathrm{Na} \mathrm{CH}$, et al. Eleven years of experience with the neurologic complications in Korean patients vith acute aortic dissection: a retrospective study. BMC Neurology 2013; 13: 46.

9. Sinatra R, Melina G, Pulitani I, et al. Emergency operation for acute type A aortic dissection: neurologic complications and early mortality. Ann Thorac Surg 2001; 71: 33-38.

10. Kim JB, Chung $\mathrm{CH}$, Moon $\mathrm{DH}$, et al. Total arch repair versus hemiarch repair in the management of acute DeBakey type I aortic dissection. Eur J Cardiothorac Surg 2011; 40: 881-889.

11. Wiedemann D, Kocher A, Dorfmeister M, et al. Effect of cerebral protection strategy on outcome of patients vith Stanford type A aortic dissection. J Thorac Cardiovasc Surg 2013; 146: 647-655.

12. Orihashi K. Acute type A aortic dissection: for further improvement of outcomes. Ann Vasc Dis 2012; 5: 310-320.

13. Estera AL, Garami Z, Miller CC, et al. Acute type A aortic dissection complicated by stroke: can immediate repair be performed safely? J Thorac Cardiovasc Surg 2006; 132: 1404-1408.

14. Czerny $M$, Krähenbühl E, Reineke $D$, et al. Mortality and neurologic injury after surgical repair with hypothermic circulatory arrest in acute and chronic proximal thoracic aortic pathology. Effect of age on outcome. Circulation 2011; 124: 1407-1413.

15. Morimoto N, Okada K, Okita Y. Lack of neurologic improvement after aortic repair for acute type A aortic dissection complicated by cerebral malperfusion: predictors and association with survival. J Thorac Cardiovasc Surg 2011; 142: 1540-1544

16. Tsukube T, Hayashi MD, Kawahira T, et al. Neurological outcomes after imeddiate aortic repair for acute type A aortic dissection complicated by comma. Circulation 2011; 124 (Suppl 1): S163-S167.

17. Easo J, Weigang E, Hölzl PF, et al.; the GERAADA study group. Influence of operative strategy for the aortic arch in DeBakey type I aortic dissection: analysis of the German Registry for Acute Aortc Dissection Type A. J Thorac Cardiovasc Surg 2012; 144: 617-623.

18. Most H, Reinhard B, Gahl B, et al. Is surgery in acute aortic dissection type A still contraindicated in the presence of preoperative neurological syptoms?. Eur J Cardiothorac Surg 2015; 48: 945-950.

19. Lee HK, Kim GJ, Cho JY, et al. Comparison of the outcomes between axillary and femoral artery cannulation for acute type $A$ aortic dissection. Korean J Thorac Cardiovasc Surg 2012; 45: 85-90.

20. Tiwari KK, Murzi M, Bevilacqua S, et al. Which cannulation (ascending aortic cannulation or peripheral arterial cannulation) is better for acute type A aortic dissection surgery? Interact Cardiovasc Thorac Surg 2010; 10: 797-802.

21. Immer FF, Moser B, Krähenbühl ES, et al. Arterial access through the right subclavian artery in surgery of the aortic arch improves neurologic outcome and mid-term quality of life. Ann Thorac Surg 2008; 85: 1614-1618. 